\title{
Covid-19 Salgını ve Türkiye: Göç Yönetişimi Üzerindeki Etkileri
}

\author{
DOI: $10.26466 /$ opus. 883997
}

$*$

\section{Zișan Korkmaz Özcan *}

* Dr. Öğr. Üyesi, Süleyman Demirel Üniversitesi İ̈BF Isparta/Türkiye E-Posta: zisankorkmaz@sdu.edu.tr

ORCID: $\underline{0000-0002-5842-8638}$

\section{Öz}

Çeşitli kurum ve kuruluşları kapsayan, bunların aralarındaki ilişkileri ve etkileşimi ifade etmek için kullamılan yönetişim, uğradı̆̆ı değişim evresi içerisinde göç yönetişimi kavramını karşımıza çıkarmıştır. COVID-19 salgını ve süreci her alanı etkilediği gibi göç olgusu konusunu da etkilemiştir. Belirlenmiş tek bir amaç için değil, insan haklarına dayalı, paydaşlara sahip, yerinden yönetişimci bir anlayış ile hareket etmek göç yönetişimi açısından oldukça önemlidir. Bu açıdan çalışmanın asıl amacı konuları kendisini ve toplumdaki diğer paydaşları dâhil ederek çözümlemeye odakl, kaynakları doğru bir şekilde yönlendirmeye çalışan göç yönetişim anlayışının COVID-19 sürecinde Türkiye üzerindeki etkilerine değinmektir. Çalışma gö̧̧ yönetişiminin kurumsal yapılanmasında rol oynayan merkezi yönetim, merkezi yönetimin taşra teşkilatı ve yerel yönetimler ile göç yönetişiminin önemli bir parçası olan sivil toplum kuruluşların kapsamaktadır. Bu çalışmada nitel araştırma yöntemlerinden söylem analizi tekniğgi kullanılmıştır. Veri olarak İçişleri Bakanlığı Göç İdaresi Genel Müdürü'nün konuşması, Türkiye ve Belediyeler Birliği Başkanının konuşmalarl, Sivil Toplumla İlişkiler Genel Müdürlüğ̈̈ Dış İlişkiler Dairesi Başkanı konuşması, Uluslararası Göç Örgütü Türkiye Acil Durum Program Koordinatörü'nün konuşmaları ele alınmıştır. Sonuç olarak göç yönetişim olgusunun doğru işleyebilmesi için kamu yönetimi, sivil toplum kuruluşları ve uluslararası örgütlerin işbirliği halinde çalışmasındaki öneme vurgu yapılmış, ayrıca COVID-19 sürecinin olumsuz etkilerinin aşılabilmesi amacıyla göçmenlere yönelik çeşitli kamu politikalarının üretilmesi gerektiği ortaya koyulmuştur.

Anahtar Kelimeler: göç yönetişimi, covı-19, söylem analizi. 


\title{
Covid-19 Epidemic and Turkey: Migration Governance Effects
}

\begin{abstract}
The governance, which includes various institutions and organizations and is used to express the relationships and interactions between them, has presented the concept of migration governance within the phase of change it has undergone. The COVID-19 pandemic and its process have affected every area as well as the migration phenomenon. It is very important for migration governance to act with a governance-based understanding based on human rights, possessing stakeholders, and not to act for a single purpose. In this respect, the main purpose of the study is to address the effects of migration governance approach on Turkey during the COVID-19 process, which is focused on analysis by including other stakeholders and trying to direct resources correctly. The study covers the central government, provincial organizations and local governments that play a role in the institutional structuring of migration governance, and non-governmental organizations that are an important part of migration governance. Discourse analysis technique, one of the qualitative research methods, was used in this study. As the data, conversation of The Interior Ministry Immigration Administration General Director, conversation of the president of the Union of Turkey and Municipalities, conversation of Civil Society Relations Directorate General Chairman of the External Relations Department, Conversation of IOM Turkey Emergency Program Coordinator, were discussed. As a result, emphasis was placed on the importance of public administration, non-governmental organizations and international organizations working in cooperation in order for the phenomenon of migration governance to function correctly, and it was also revealed that various public policies for migrants should be produced in order to overcome the negative effects of the COVID-19.
\end{abstract}

Keywords: migration governance, covid-19, discourse analysis. 


\section{Giriş}

Yeni Koronavirüs Hastalığ (COVID-19), ilk olarak Çin'in Vuhan Kenti'nde Aralık ayı sonlarında hayvan pazarında deniz ürünü bulunanlarda tespit edilmiş, solunum yolları belirtisi olan öksürük, ateş, nefes darlığı şeklinde görülen, insandan insana bulaşarak dünya ülkelerine yayılan bir virüs olarak tanımlanmıştır (Sağlık Bakanlığı, 2020). Geçmişten günümüze değin birçok ülke salgın ile mücadele etmiş, bazen bu mücadeleler kısa sürede başarıya ulaşmış bazen de uzun dönemde tüm dünyayı etkileyen küresel bir boyuta geçmiştir. Ülkelerin salgın hastalıklarla mücadele kapsamında uyguladığı politikalar hemen her alanı ve kesimi etkilemiştir. Özellikle kamu sektörü ve özel sektör hizmeti sunanlar ile bu hizmetlere aracilık eden bölgesel, ulusal ya da uluslararası kuruluşlar sürecin olumsuzluklarından etkilenmektedirler. Tüm dünyada COVID-19 pandemi süreci ile çalışan, emekli, işsiz, öğrenci, genç ya da yaşlı birçok grup bu süreçten etkilendiği gibi göçmen ve mülteci olarak adlandırdığımız kesimdeki kişi ve aileleri de bu süreçten olumsuz yönde etkilenen gruplar arasında yerini almıştır.

Türkiye, bulunduğu konum açısından önemli göç yolları üzerinde yer almaktadır. Geçmişten günümüze birçok göçe tanıklık etmiş ve ev sahipliği yaparak, $\mathrm{AB}$ ülkelerine yönelen düzensiz göçmenler açısından konumu, sosyokültürel ve insani özellikleri sebebiyle vazgeçilmez bir özellik taşımaktadır. Avrupa ülkeleri, Amerika ve diğer gelişmiş ülkelere Türkiye üzerinden ulaşma fikri, Türkiye'nin bağlantı amaçlı kullanılan ve uluslararası göç alan bir ülke konuma gelmesine sebep olmuştur (Kolukırık, 2014, s.40). Türkiye'nin, komşu ülkelere göre daha iyi ekonomik şartlar sunması da bunun sebepleri arasındadır. Dolayısıyla ülkemize yolu düşen düzensiz göçmenlerin bir kısmı transit geçiş için geldikleri Türkiye'yi, hedef ülke olarak görmekte; kalıcı olmak için gelen bazı göçmenler de geçiş ülkesi olarak sonradan da bu durumu kullanabilmektedir. Bazı göçmenlerin arasında ise sığınma talebinde bulunarak talepleri reddedilmiş olan, fakat yine de ülkesine geri gitmek istemeyen, Türkiye'de kalıp kaçak işçi olarak çalışmak isteyenler yer almaktadır (Tepealtı, 2019, s.131).

$A B^{\prime}$ nin kamu sektörü, özel sektör ve sivil toplum kuruluşları aktörleri, üniversiteler ve araştırma kurumları, dernek ve onların birbiriyle etkileşimleri göç yönetişimi açısından iletişim ve bilgi ağını sağlayan unsurlardır. Göç yönetişiminde iletişim ve bilgi konusundaki işbirliğinin doğru işleyebilmesi 
$A B$ için oldukça önemlidir. Bu bağlamda, göç yönetişimine dair aktörlerin, kurumların ve ajansların ulusalüstü düzeyde etki düzeyinin artırılması, yapılandırmalara gidilmesi ve eğitsel programların oluşturulması gerekmektedir. (Aliu vd., 2017, s.102). Uluslararası işbirliği kapsamında göçe ev sahipliği yapan ülkeler, göçmen ve mülteciler ile onların ailelerinin yaşadıkları zorluklara cevap verme açısından önemli bir araçtır. Fakat insan hareketlerine ilişkin olarak devletlerin davranışlarını düzenlemek ve uluslararası işbirliğinin gerçekleştirilebilmesi için hangi önlemlerin veya hangi pratik çözümlerin alınması gerektiği ile ilgili kesin bir analiz yapılmamıştır (Papademetriou, 2011, s.1).

Çalışma üç ana düzlemde ele alınmıştır. İlk olarak göç konusunda Türkiye'nin Göç İdaresi Genel Müdürlüğü çerçevesinde göç yönetişimine dahil ettiğimiz teşkilat yapısı, ikinci olarak göç yönetişimi çerçevesinde geçmişten günümüze kamu politikaları, üçüncü olarak ise söylem analizi ile nitel bir araştırma gerçekleştirilmiştir. Bu açıdan, çalışma kapsamına dahil edilen merkezi yönetimin merkez ve taşra teşkilatları ile yerel yönetimler kamu kesimi açısından; sivil toplum kuruluşları ile uluslararası örgütler ise işbirliği hareketinin gerçekleştirilmesinde önemli diğer kesimleri oluşturarak çalışmaya dahil edilmiştir. Belirlenmiş olan stratejik konular bu çerçevede COVID-19 sürecinde göç bağlamında konuşmalar yapan yetkili kişiler üzerinde gerçekleştirilmiştir. COVID-19 sürecinde göç yönetişiminin ne kadar önemli olduğuna, salgın sebebiyle göçmenlerin etkilendiği çeşitli olumsuzluklara, istihdam ve katılımın desteklenmesi amaçlı yapılması gerekenlere vurgular yapılmıştır.

\section{Göç Olgusu ve Türkiye'deki Yönetsel Yapılanması}

İnsanların daha iyi ve güvenilir olanı arayarak bulma isteği göç hareketlerinin temeldeki çıkış noktasını oluşturmaktadır. Kişiler doğal afet, ekonomik gerekçe, savaş, zulümden kaçınma isteği gibi çeşitli sebeplerden dolayı göç etmektedir. Göç hareketleri çeşitli ulusal ve uluslararası şekillerde gerçekleşebilmektedir. Ulusal boyut bakımından göç hareketleri iç göçü karşımıza ç1karırken; bir ülkenin sınırları dışında ortaya çıkan göçler ise uluslararası göç olarak tanımlanmaktadır (Kara vd., 2016, s.2).

Göç ederek başka bir ülkeye giden yabancılar, ülkemize geldiklerinde ya da tekrar kendi ülkelerine döndükleri zaman hayatta kalabilmek için tüm 
yetkinliklerini gösterebilecek seviyeyi kazandırmak göç yönetiminde oldukça önemlidir. Göç yönetimi artık küreselleşme ile birlikte yeniden şekil almakta, göç yönetişimi adı ile ortaya çıkmaktadır. Türkiye, göç yolları güzergahında yer alması, coğrafi ve jeopolitik konum açısından elverişli olması, sahip olduğu kültürel özellikler bakımından oldukça avantajlı bir ülkedir. Bu durum Türkiye'nin göç almakta olan bir ülke konumuna gelmesinin bir sebebi olmakta; uluslararası ve sektörel yönden pekçok kurum ve kuruluş ile devletlerin işbirliği halinde hareket etmesini gerekli kılmaktadır. Zira Türkiye'nin, "hedef ülke" konumunda yer alması beraberinde uygulanacak olan etkin göç yönetim politikası uygulanmalarında ve sorumlu tutulabilecek teşkilatın nasıl bir yapıya sahip olacağının belirlenmesinde önemli yükümlülükler altına girdirmektedir (Korkmaz Özcan, 2018, s.120).

Göç konusunda yürütülen çalışmaların ve uygulamaların doğru işleyişi, personel yapısının görevlendirilmesi ve koordinasyonu teşkilat yapılanmasını karşımıza çıkarmaktadır. Bu yapılanmanın içerisine merkez teşkilatı, merkez teşkilatının taşra örgütlenmesi, yerel yönetim birimleri ve uluslararası kuruluşlar girmektedir. Göç İdaresinin merkez teşkilat yapısının içerisine, göç yönetimi ve düzenlenmesi konusunda "Göç Politika ve Projeleri Dairesi Başkanlığı", ileride gerçekleşebilecek göçleri hesaplayan "Strateji Geliştirme Dairesi Başkanlığı", verilerin toplanmasını sağlayan "Bilgi Teknolojileri Dairesi Başkanlığı", yurt dışı ile kurum arasında iletişim sağlayan "Dış İlişkiler Dairesi Başkanlığı", yardım amaçlı bilgilendirmeler yapan "Destek Hizmetleri", avukatlık işlemlerini yerine getiren "Hukuk Müşavirliği", "İnsan Kaynakları Dairesi Başkanlığı", çocukların eğitimi konusunda "Eğitim Dairesi Başkanlığı" girmektedir. Bununla birlikte taşra teşkilat yapısı içerisine "İl Göç İdaresi Müdürlükleri" girerken, yurtdışı birimi olarak ise göçler alanında yurt dişı ayağı olan “Göç Müşavirlikleri” ve "Göç Ataşelikleri” yer almaktadir.

Göç İdaresi Genel Müdürlüğü'nün, göç ile ilgili strateji ve politika uygulamaları, konusuna göre ilgili kurum ve kuruluşların aralarında koordinasyonun sağlanması, yabancı kişilerin Türkiye'deki giriş-çıkışları ile kalış zamanları, onların sınır dışı edilmesi, uluslararası anlamda korunmaları, geçici korunmaları ile insan ticaretinde mağdur olanların korunmasında iş ve işlemler yürütmek üzere çeşitli faaliyetleri yer almaktadır. Sivil bir yapılanmaya sahip olan Genel Müdürlügün kurulmasında amaç; çalışmaların alanında uzman, uluslararası işbirliğine açık, süreçlerin dinamik yapısına ayak 
uydurabilen mekanizmalar oluşturarak, gelen ve gelecek olan tüm yabanc1ların iş ve işlemlerini, birey odaklı politikalar geliştirmek ve çözmeye çalışmaktır. (goc.gov.tr). Bu durum bize karma örgütlenme modelinin merkezi yönetim, taşra yönetimi, yerel yönetimler ve uluslararası kuruluşlardan oluşmasıyla, dinamik çerçevede işbirliğini önemseyen yönetişimci yaklaşıma yönelik konuya bakılmasının önemini göstermektedir.

2020 Dünya Göç Raporuna göre, uluslararası göçmen sayısı geçtiğimiz elli yılda artmış, 2019'da doğdukları ülke dışında başka bir ülkeye giderek yaşayanların tahmini kişi sayısı 272 milyon olarak kaydedilmiştir. Bu rakamların 1990'da kaydedilmiş olan rakamlardan (153 milyon) 119 milyon ve 1970 y1lında kaydedilmiş olan rakamdan (84 milyon) ise üç katından daha fazla olduğu görülmüştür (2020 Dünya Göç Raporu, 9). Son zamanlarda ortaya ç1kan COVID-19 salgını, uluslararası sinıların kapanmasıyla dünya genelinde hareketsiz bir süreci doğurmuş, dünyanın pek çok yerinde göçmenler evlerine gönderilmiş, başka ülkelerde çalışma fırsatı yakalayamamış ya da işleri ortadan kalktı̆̆ için memleketlerine geri dönmek zorunda kalmış, yurtiçinde veya yurtdışında ekonomik sıkıntılar ortaya çıkmıştır. İnsanların uluslararası hareketliliklerine yönelik yapılmış birçok anlaşma, kişilere ve devletlere göçün sonuçlarının üstesinden gelebilmelerine yönelik hazırlanmıştır (Newland, 2020, s.1). Ancak salgın sürecinde yaşananlar özellikle göçmenler bakımından birçok sorunu da beraberinde getirmiş, işbirliği hareketlerinde zorlanmalara sebep olmuştur.

Birleşmiş Milletler tarafından yayınlanmış olan International Migration 2020 Highlights raporuna göre, salgının uluslararası göçmen stokundaki büyümeyi 2020 yılı ortasına kadar yaklaşık iki milyon civarında yavaşlatmış olabileceği tahmin edilmektedir. Uluslararası göçmen sayısındaki artış, 2000 yılında 173 milyon, 2010 yılında 221 milyon iken, 2020 yılında ise kendi ülkesinin dişında yaşayan 281 milyon kişiye ulaşmıştır. Şu anda, uluslararası göçmenler dünyadaki nüfusun yaklaşık \% 3.6' sını temsil etmektedir (International Migration 2020 Highlights).

Türkiye açısından Göç İdaresi Genel Müdürlüğü verilerine göre ülkemizdeki kitlesel göç hareketleri Cumhuriyet'in kurulma sürecinde ve sonrasında devam etmiş, 1922' den günümüze kadar yaklaşık 5,5 milyon kişiyi bünyesinde toplamıştır. Bu sayıya çalışma ve eğitim gibi amaçlarla gelen yabancılar dahil edilmemiştir. 1922-2013 tarihleri arasında Yunanistan, Balkanlar, Almanya, Irak, Bulgaristan, Bosna, Kosova, Makedonya ve Suriye gibi çeşitli 
ülkelerden yaklaşık 1,5 milyon kişi Türkiye'ye göç etmiştir. 2011'de Suriye' deki iç savaştan dolayı Türkiye'ye yaklaşık 1.760 milyon kişi sığınmış ve bu sayı ile yaklaşık 3 milyon kişiye ulaşılmıştır (goc.gov.tr). Göç ile birlikte farklı farklı tarihlerde Türkiye'de bulunanların bir kısmı daha sonraki yıllarda Türkiye'den ayrılırken, büyük bir kısmı ise önemli bir Suriyeli nüfus oranı ile halen ülkemizde yaşamını idame etmektedir. (Demirhan ve Aslan, 2015, s.35). Günümüzde Göç İdaresi Genel Müdürlüğü raporlarına göre düzensiz göçmen sayılarına bakıldığında 2019 yılı itibariyle 454.662 kişi olduğu, 2020 yılında 122.302 kişiye düştüğünü, 2021 yılı için bu rakamın 9.653 kişi olarak kaydedildiği görülmektedir. Göç İdaresi Genel Müdürlüğü verileri Türkiye'de 3,6 milyon "geçici koruma" altında Suriyeli olduğunu göstermektedir. Türkiye'deki Suriyeli mültecilerin yaklaşık \%2'si kamplarda ve çoğunluğu İstanbul, Gaziantep, Urfa ve Hatay, Kilis gibi şehirlerde yaşamaktadır.

\section{Türkiye'de Kamu Politikaları Açısından Göç Yönetişimine Bakış}

Eğer göç iyi yönetilebilirse göçmenler, ev sahibi ülke, özel sektör ve göçmenlerin geldiği toplumlar göç olgusundan faydalanabilmektedir. Göçmenlerin birleştirilmesi ve kaynaştırılması, sosyal uyum konusunda etkili bir göç yönetimi politikası parçasıdır. Etkili bir uyumlaştırma politikasının uygulanmasındaki en önemli zorluklardan biri, göçmenlere yönelik insan haklarının korunarak, onlara eşit firsatlar sunulmasında, istihdamda ve iş piyasasında, bölgesel kalkınmada, ulusal ve uluslararası güvenlikte, sosyal uyum alanında, sağlık, eğitim ve vatandaşlık tanınması konusunda temel politika alanlarıyla karşılaştırma sağlanabilmektedir. IOM zorluklarla ilgili olarak çeşitli ortak amaçlar için politikalar geliştirmekte ve somut anlamda destek tedbirlerinin belirlenmesi için hükümetlerle/devletle, sivil toplum ve özel sektör paydaşlarıyla çalışmaktadır (turkey.iom.int).

Göç yönetim süreci için önemli bir kavram olarak karşımıza çıkan göç yönetişiminin iki tanımlayıc özelliği vardır. İlk olarak, anlamda yer alan "govern" sözcüğü uluslararası olarak açkça etiketlenmemiş bir karamdır. Küresel yönetişim alanları tarafından düzenlenen göç, devletlerin uluslararası göçe karşı tepkilerini düzenler. Ayrıca iki taraflı, bölgesel ve bölgelerarası bir dizi kurumun katılımını ön planda tutan çok düzeyli, devletlerin ve diğer aktörlerin resmi olmayan ağları anlamındadır (Betts, 2008, s. 9). Zira göç yönetişimi ulusal, bölgesel, bölgelerarası ve uluslararası yapısı ile küresel 
yönetişimin parçası konumundadır (Kara vd., 2016, s. 4). Değişen yönetim anlayışı ile birlikte göç olgusuna yönelik kamu politikaları da farklılaşmış ve yönetim anlayışındaki değişimi yaptığı düzenlemelere ve uygulama birliklerine konu etmiştir. Geçmişten günümüze göçe bakış açısında yaşanan kamu politikaları şu şekildedir:

- 1983 tarihli Mülteci Misafirhaneleri Yönetmeliği,

- 1985 tarihli Türkiye'de öğrenim gören yabancı uyruklu öğrenciler yönetmeliği

- 1994 tarihli Türkiye'ye İltica Eden Veya Başka Bir Ülkeye İltica Etmek Üzere Türkiye'den İkamet İzni Talep Edilen Münferit Yabanclar ile Topluca Sığınma için Sınırlarımıza Gelen Yabancılara ve Nüfus Hareketlerine Uygulanacak Usul Ve Esaslar Hakkında Yönetmelik,

- 2003 Tarihli, Doğrudan Yabancı Yatırımlarda Yabanc Uyruklu Personel İstihdamı Hakkında Yönetmelik,

- 2003 tarihli, Yabancıların Çalışma İzinleri Hakkında Kanunun Uygulanma Yönetmeliği,

- 2006 tarihli Türkiye'de Oturan Yabanciların Nüfus Kayıtlarının Tutulması Hakkında Yönetmelik,

- 2012 tarihli Doğrudan Yabancı Yatırımlar Kanunu Uygulama Yönetmelik.

Bu tarihlerden sonra 11 Nisan 2013 tarihli Resmî Gazete'de 6458 sayılı Yabancılar ve Uluslararası Koruma Kanunu (YUKK) yayımlanarak yürürlüğe girmiş, insan hakları temelinde, özgürlük ve güvenlik arasındaki dengenin sağlandığı, uluslararası insan haklarındaki normlarla ve $\mathrm{AB}$ müktesebatına uyumlu, göç için gerekli hukuksal, idari ve fiziksel alt yapıya yönelik en uygun olabilecek yönetsel göç yapılanması kurulmuştur (Türkiye Göç Raporu, 2016: 25) Göç ile ilgili problemlerin çözüme kavuşturulması ve etkin yönetilebilmesi için dünyadaki çeşitli örnekler gibi, görev alanlarına uygun insan haklarına odaklı, stratejik ve güncel politikalar geliştirip uygulayabilen, nitelikli personele ve başarılı alt yapıya sahip kurumsal yapılanmaya ihtiyaç duyulmaktadır. Bu bağlamda, Türkiye 'nin göçe yönelik etkin politikalar belirleyebilmesi ve uygulayabilmesi için çeşitli düzenlemeler getirilmiştir. Bu düzenlemelerin en önemlisi ise 11.04.2013 tarihli ve 28615 sayılı Resmi Gazetede yayımlanarak yürürlüğe giren 6458 sayılı Yabancılar ve Uluslararası Koruma Kanunu'dur. Bu kanun özellikle göç yönetimi konusunda göçmenlerin ve uluslararası koruma arayan kişilerin haklarını teminat altına alan bir yasal 
zemine oturtulmuştur. Ayrıca kanunla göçmenlerin ve mültecilerin hakları yasal çerçevede uluslararası standartlara uygun hale getirilmiş, 81 il ve 148 ilçede, özellikle yurtdışında teşkilatlanma hedeflenmiştir (goc.gov.tr).

Ülkelerindeki iç karışıklıklar sebebiyle Suriye'den gelen yabancılara sağlanacak "Geçici Koruma" ile hukuksal dayanak sağlanmıştır. Bu açıdan 2014 tarihli Geçici Koruma Yönetmeliği kapsamındaki yabancilardan gönüllü olarak ülkelerine dönecek kişiler için gerekli kolaylıklar sağlanır ve imkân dahilinde destek verilmektedir. Ayrıca Genel Müdürlük, "gönüllü geri dönüş çalışmalarını, ilgili ülke makamları, kamu kurum ve kuruluşları, uluslararası kuruluşlar, sivil toplum kuruluşları ile işbirliği içinde planlayabilir, proje ve program hazırlayabilir ve uygulayabilir" şeklinde belirterek yönetişim kavramı ismen geçmese de işbirliği anlamı bakımından önemli bir kamu politikası anlayışı olarak görülmektedir.

2018'de "The Global Compact For Migration" olarak adlandırılan, Birleşmiş Milletler üyeleri tarafından kabul edilen Güvenli, Sistemli ve Düzenli Göç için Küresel İlkeler Sözleşmesi, ulus ötesi olması özelliği taşımaktadır. Sözleşmeye göçün üstesinden hiçbir devletin tek başına gelemeyeceğinin farkında olan, yasal bağlayıcılığı olmayan, uluslararası, bölgesel, ikili işbirliği ve diyalog gerektiren işbirliği hareketi çerçevesinde bakılmaktadır (europarl.europa.eu). Bu açıdan küreselleşme ile hesap verebilir, şeffaf, katılım esaslı, vatandaşa ve sonuca odaklı, kamu sektörü, özel sektör, sivil toplum kuruluşları ve uluslararası kuruluşları işin içine katmaya çalışan yönetişimci bir yapılanma karşımıza çıkmaktadır (Korkmaz Özcan ve Mesci, 2018: 35). Ayrıca 2019-2020 yıllarında birçok üniversite içerisinde göç hareketlerinin demografik, toplumsal, kültürel, eğitsel, hukuki ve ekonomik, siyasi, dini görünümleri üzerine çalışmalar ile göç ve göçmenlerin ekonomik, sosyal ve politik etkileri üzerinde araştırmalar yapmak üzere oluşturulmuş Göç Araştırmaları ve Uygulama ve Araştırma Merkezi Yönetmelikleri çıkarılmıştır.

Resmi Gazetede yayımlanarak yürürlüğe giren 23.05.2020 tarih ve 31135 sayılı Göç İdaresi Genel Müdürlüğü Yayın Yönetmeliği kapsamında, Göç İdaresi Genel Müdürlüğü’nün bastığı bütün yayınların planlanması, basılıp, dağıtılması konusunda kuralları belirleyerek, yayın hizmetlerinin etkili şekilde yürütülmesi konusu yer almaktadır (mevzuat.gov.tr). Güvenli, Sistemli ve Düzenli Göç için Küresel İlkeler Sözleşmesi pandemi süreci ile birlikte aciliyet gerektiren çeşitli hedefler içermektedir. Bunlar arasında göç esnasında güvenlik açıklarının azaltılması, konsolosluk hizmetlerinin güçlendirilmesi 
ve göçmenlere sağlık hizmetleri gibi temel hizmetlere erişim sağlanması dahildir. Ayrıca, uluslararası göçün yeniden başlatılmasına yardımcı olabilecek, tüm göçmenler için yasal kimlik ve belgeler ile göçmenleri kabul ve kalış için uygun kanallara yönlendirmek amaciyla çeşitli prosedürler tekrar düzenlenmelidir (Newland, 2020, s.1). Zira COVID-19 süreci ile birlikte artık uluslararası ve ulusal sınırlandırmalar yapılarak, dünya genelinde seyahatlere yönelik gelen kısıtlamalar birçok sorunu da beraberinde getirmiştir. Bu bağlamda insan hareketliliğinin azaldığı bu süreç göç yönetimi üzerinde de değişimleri ortaya koymaktadır.

\section{Yöntem}

Bu çalışmada nitel araştırma yöntemlerinden söylem analizi tekniği kullanılmıştır. Göç yönetişimi bakımından işbirliğinin gerekli görüldüğü ve kurumsal yapılanmasında rol oynayan merkezi yönetim, merkezi yönetimin taşra teşkilatı, yerel yönetimler, sivil toplum kuruluşları ve uluslararası örgütler veri toplanmasında ele alınan alanlardır. Veriler pandemi sürecinde göç alanında konuşmaları yer alan kişiler üzerinden toplanmıştır. Bu kapsamda kamu sektöründen İçişleri Bakanlığ1 Göç İdaresi Genel Müdürü Savaş Ünlü'nün konuşması, Türkiye Belediyeler Birliği (TBB) ve Gaziantep Büyükşehir Belediye Başkanı Fatma Şahin'in konuşması, sivil toplum kuruluşu olarak Sivil Toplumla İlişkiler Genel Müdürlüğü Dış İlişkiler Dairesi Başkanı Ahmet Türköz'ün konuşması, uluslararası örgüt anlamında ise Uluslararası Göç Örgütü IOM Türkiye Acil Durum Program Koordinatörü Mazen Aboulhosn'un konuşması ele alınmıştır. Söylem analizi söylem üretme yolu olarak görülebilmektedir. Veri, analiz ve analizden elde edilen sonuçlara dayanarak gerçekleştirilen söylem analizinde örneklem büyüklüğü önemli olmamakta, analizlerde kişilere yönelik sayısal bir sınır yer almamaktadır. Dolayısıyla kullanılan dil ve söylenen sözler çözümlenmeye çalışılmaktadır. Zira söylem analizinde konuyu yazıll, sözlü ya da sözsüz içerikli metinler oluşturmaktadır (Sözen, 1999). Bu açıdan çalışmada metinlerin analizinde kullanılmakta olan araştırma soruları şu şekildedir: Göç yönetişiminde işbirliği neden önemli? COVID-19 salgınında göçmenler nelerden olumsuz etkilenmekte? Göçmenlerin çalışma alanlarına dahil edilebilmesi ve pandemi sürecinin sorunlarının aşılabilmesi için neler yapılmalı? 
Sorulan soruların cevaplanması için kullanılan söylem konuları ve içerikleri ilk olarak belirlenmiştir. Bu açıdan sorulara verilen cevaplar incelenerek, söylemsel stratejiler belirlenmiş, daha sonra ise söylemsel stratejilerin gerçekleştirilmesi için kullanılan dilsel araçlar ile ortaya çıkan konuşmalar incelenmiştir (Düzgit, 2011, s.56).

\section{Bulgular}

Yapılan söylem analizi sonucunda konuşmalarda aşağıdaki başlıkların vurgulandığı ortaya çıkarılmıştır.

\section{COVID-19 Sürecinde Göç Yönetişiminin (İşbirliğinin) Önemine Vurgu}

Göç İdaresi Genel Müdürü Savaş Ünlü: “Ülkemiz, Avrupa’ da hiçbir ülkenin altından kalkamayacağı bir yükü, Türk milletinin misafirperverlik ve mağdura sahip çıkma gibi tarihsel kodları ile birlikte önemli bir problem yaşamadan yürütmeyi başarmıştır. Sadece yabancılar ve göç yönetimi ile ilgili süreçlerde değil, kamuya ait tüm süreçlerde sivil toplum kamunun en önemli paydaşıdır." Ünlü'nün bu konuşması ile göç konusunda özellikle sivil toplum kuruluşlarının kamunun yetişemediği noktalarda çok önemli bir işlevi yerine getireceğine değinmektedir. Ayrıca gerçekleştirilen işbirlikleri ile göç yönetiminin daha sorunsuz şekilde yapılabileceğinin vurgusu yapılarak kamu sektörünün tek başına sorunlar ile başa çıkabilmesinin güç olacağı vurgulanmıştir.

Türkiye Belediyeler Birliği (TBB) ve Gaziantep Büyükşehir Belediye Başkanı Fatma Şahin, sosyal izolasyon, sosyal mesafe ve hijyen konusunda 14 kuralı halka anlattıklarını ifade etmiş, Gaziantep'te salgınla mücadelede neler yapıldığını anlatarak, “...Artık özel ve devlet hastanesi ayrımı kalmadan işçiçiftçi, kadın-erkek demeden sosyal sağlık sistemi kuruldu. Yerelle merkez koordine olduğu zaman büyük bir başarı hikayesi oluştu." şeklinde konuşmuştur. Bu bakımdan işbirliği hareketinin özellikle COVID-19 süreci açısından oldukça önemli olduğunu vurgulamıştır.

Sivil Toplumla İlişkiler Genel Müdürlüğü Dış İlişkiler Dairesi Başkanı Ahmet TÜRKÖZ “Türkiye' de göç ve göçmen konusunda faaliyet gösteren STK sayısı 1074 civarında" olduğunu belirterek, "Kamu-STK iş birliği geliştirilmesi gereken bir alandır. Çünkü STK'lar bağımsız yapılardır. İşlerin koordineli bir şekilde yürütülmesi açısından gerekli mercilere ihtiyaç var." 
değerlendirmesini yapmıştır. COVID-19 sebebiyle "Kamu, STK Uyum Buluşmaları" olarak adlandırılan toplantıların her birisi çevrim içi olarak gerçekleştirilmiş, sivil toplum kuruluşlarının kamu desteği alarak, işbirliği halinde göçmen konusuna destek sağlaması gerektiğine vurgu yapılmıştır. Ayrıca IOM, ülke genelinde İl Göç İdareleri ile işbirliği doğrultusunda göçmenlere kişisel koruyucu ekipman ve ihtiyaç duyulan malzemeleri temin ederek, denizde kurtarılan ve Yunanistan kara sınırında bulunan göçmenlere insani yardımların yapılmasını gerçekleştirmektedir.

Belediyelerin, vatandaş ve göçmenleri kapsayan hizmetlerini sunabilmesi açısından STK'larının alanda elde ettiği birikimlerden yararlanılmasına ihtiyaç vardır. Bu anlamda STK'ları özellikle koruma, geçim kaynaklarına erişim ve sosyal uyum bakımından deneyimli ve uzman personele, anlamlı bir çözüm potansiyeli oluşturmaktadır. Amacı gerçekleştirmek için belediye ile sivil toplum kuruluşlarının gerçekleştirdikleri işbirlikleri, hukuka uygun olmalıdır. Bu bağlamda belediyeler, sivil toplum kuruluşlarına işleri devretmesi noktasında yasal bir dayanakla hareket etmelidir (Kocaoğulları, 2020, s. 36).

\section{COVID-19 Salgınından Göçmenlerin Olumsuz Etkilenmelerine Vurgu}

IOM Türkiye Acil Durum Program Koordinatörü Mazen Aboulhosn, “COVID-19 salgını, özellikle İstanbul, İzmir ve Gaziantep gibi büyük şehirlerde yaşayan göçmen ve mülteci toplulukları vurdu" açıklamasında bulunmuştur. Ayrıca bu süreçte iş kaybına ilk uğrayanların arasında yüzbinlerce göçmenin yer aldığını, bu açıdan maddi anlamda aileleri ile birlikte yükün altında kaldıklarını söyleyerek, birçoğunun ilaç, gıda ve sağlık anlamında çeşitli hizmetleri hala karşılayamadıklarını sözlerine eklemiştir (turkey.iom.int). Aboulhosn'un bu açılamasından Covıd-19'un göçmenler açısından oldukça zor bir süreç olduğu vurgulanmıştır. Ayrıca IOM'un çeşitli illerdeki göçmen aileler üzerinde gerçekleştirdiği saha araştırmaları da bunu doğrulamaktadır. Elde edilen veriler ışığında COVID-19 sürecinden sağlık ve ekonomik anlamda göçmenlerin orantısız şekilde etkilendiği ortaya konulmaktadır. Göç olgusu ile beraber ortaya çıkan sağlık, ekonomik ve toplumsal anlamda yaşanan pek çok sıkıntı suç oranlarını da olumsuz yönde etkileyebilecektir. Bu durum toplumsal anlamda düzensizliklerin yaşandı̆̆ı bir süreci doğuracak, yeni yasal ve politik düzenlemelere sebep olacaktır. 
Göç başlı başına suça neden olan bir faaliyet gibi görülmese de, göçün iyi şekilde yönetilememesi durumunda eğitimden sağlığa, ekonomiden psikolojiye pek çok anlamda sorunlara yönelik politikalar geliştirmek, ileride suça yönelik sorunlarının büyümesinin engellenmesinde oldukça önemlidir (Korkmaz Özcan ve Gül, 2019, s.1324). Özellikle COVID -19 sürecinde uluslararası ve şehirlerarası yasaklarının ihlal edilmesi, kimlik ve belgelerde sahtecilik gibi vb. konularda çeşitli olumsuz örnekler kaşımıza çıkabilmektedir.

Türkiye Belediyeler Birliği (TBB) ve Gaziantep Büyükşehir Belediye Başkanı Fatma Şahin "Yeni bir dünya kurulduğunu düşünüyorum. Bu yeni dünyada güçlü devlet tanımının değiştiğini, yalnızca kişi başına düşen milli gelir ile güçlü olunmadığını, sağlıklı kentler kurulması gerektiğini, tedarik zincirini güçlü kurmamı gerektiğini ve tedarik ve gida güvenliğini temin etmemiz gerektiğini düşünüyorum. Bu dönem bizim güçlü yönlerimizi gösteren bir zaman oldu. Çevresel kalkınmanın insani kalkınmayla birlikte ne anlama geldiğini pandemi sürecinde gördük. TBB olarak tüm çalışmalarımızı tüm paydaşlarımızla paylaşmaya hazırız." (tbb.gov.tr) şeklindeki konuşmasıyla COVID-19 ile ortaya çıkan her türlü aksaklıkların sağlıklı kentler olarak adlandırılan, sağlıklı ve yaşanabilir bir kent için yapılanması için gerekli faaliyetler olduğu ortaya koyulmuştur. Bunun için ekonomik boyutun yanında insani anlamda da yerine getirilmesi gerekenlerin diğer kurum ve kuruluşlar ile işbirliği halinde gerçekleşmesinin daha etkin olacağı vurgulamıştır.

Kentin sağlıklı olması sadece bireylerin fiziksel iyi oluşu anlamında değil, aynı zamanda psikolojik iyi oluş olarak da tüm çevrenin iyi olmasını sağlamaktır (Belli, 2019, s.1930). Sağlıklı kent, kentin sahip olduğu değerleri yenilemek, kent ulaşımı, konut alanları, yeşil alanların oluşturulması, sosyal bütünleşmeyi sağlama, toplumun gelişmesine imkan yaratma, sağlık servislerine ulaşılabilirlik sağlama, yaşama imkânı sağlama, arkadaşları ile görüşebilme, ailesinin korunması, yeme-içme ihtiyaçların karşılayabilme, güvenli ve özgür şekilde yaşama faaliyetlerinin gerçekleştirilmesi şeklinde farklı bakış ve çalışma alanlarına göre tanımlanabilmektedir (Başaran, 2007, s.208). Fiziksel ve sosyal anlamda toplumun kaynakların genişleten, düzenleyen ve insanların birbirlerini desteklemelerini sağlayarak (Goldstein, 1996, s.4), şehrin çeşitli bölümlerinin birbirleriyle iletişim kurmasının, duyarlı ve esnek kalmasının önemi üzerinde durmaktadır. Sağlıklı bir kent için şehrin gelişimsel ihtiyaçlara, organizasyonlara ve insanlara yönelik tepkilerinin uygun ve etkili 
olması; kentin değişen gereksinimleri karşılamak adına kendini değiştirme yeteneğine sahip olması gerekmektedir (Duhl, 1986, s.55).

Bir kentte göçün sonuçları olumsuzlukların yoğun olması durumu gibi görünse de taraftarlar açısından olumlu birçok varsayım ve sonuç söz konusudur. Örneğin, yurtdışına taşınmak çoğu göçmen ve aileleri için ekonomik bir fayda olarak görülmekte, alıcı ülkelerdeki işverenler tarafından göçmen işçiliğine ihtiyaç duyulması memnuniyetle karşılanmakta ve sıklıkla talep edilmekte, uluslararası göçmen örgütler tarafından yapılan ekonomik katkılar yerel topluluklara yardım ederek çeşitli hizmetleri ve altyapıyı sağlamaktadır. Ayrıca ulusal düzeyde emek ihraç eden ülkelerden gelen dövizler oldukça önemli görülmekte, işçi dövizleri ile ülke ekonomisi gelişmekte, göç yerel işsizliğe ve mali darboğazlara kısa vadeli bir çözüm sağladığı ölçüde de ülke hükümetleri özerk ulusal kalkınmayı teşvik etmektedir (Portes, 2008, s.7). Fakat COVID-19 salgını, düşük ve orta gelirli ülkelere gönderilen havale hacmini 2019 'da 548 milyar dolardan 2021'de 470 milyar dolara düşürebilmekte ve bu da 78 milyar dolar veya \% 14 kayıp anlamına gelmektedir. Bu süreçten milyonlarca göçmen ve aileleri geçim sıkıntısı yaşamış, sürdürülebilir kalkınma hedeflerine ulaşmada ilerlemeyi durdurmuştur. Bu kaybın etkilerini azaltmak için ulusal stratejilere ve uluslararası işbirliğine ihtiyaç duyulacaktır (International Migration 2020 Highlights).

\section{İstihdama Katılım ve İşgücünün Desteklenmesine Vurgu}

Türkiye Belediyeler Birliği (TBB) ve Gaziantep Büyükşehir Belediye Başkanı Fatma Şahin belediyelerin COVID-19 süreci ile nasıl mücadele ettiği sorusunu Türkiye'nin sağlık alanındaki dönüşüm politikası ve hükümet-belediyeler arasındaki işbirliği ile gerçekleştiğini belirtmiştir. Şahin aynı zamanda: "Biz sağlıkta dönüşümde yaptığımız çalışmaların dönüşlerini alıyoruz. Bu süreç bize, ne kadar doğru bir şekilde insani kalkınmaya ne kadar önem verdiğimizi söylüyor. Ekonomiyle birlikte çevresel ve insani kalkınmayı sağlayamazsak büyük sorunlar yaşanacağı mesajını veriyor. Herkes güvende değilse kimse güvende değildir." açıklamasında bulunmuştur. En büyük gücün yetişmiş insan gücü olduğunun altını çizen Şahin'in bu açıklamasından özellikle yaklaşık 500 bin nüfuslu mülteciye sahip Gaziantep için birbirini desteklemesi gereken pek çok kurum ve kuruluşun varlığı gerekmektedir. Bu 
açıdan göçmenlerin istihdama katılım ve işgücü konusu göç yönetişimi anlaminda düşünüldüğünde oldukça önemlidir.

Göçmen nüfusundaki sayısal fazlalık iş piyasasını ve iş gücü kapasitesini büyük oranda etkilemektedir. Örneğin Türkiye'de çalışma izni alarak çalışan göçmenler 35 bin civarındayken, Suriyeli mülteciler içerisinde iş piyasasında 800 bin - 1 milyon 200 bin arasında çalışan kişi olduğu tahmin edilmektedir. Türkiye' de \%40 oranında kayıt dışı işgücün olduğu tahmin edilirken bu oran tahminlerin üstünde çıkmıştır. Bu durumun sebepleri çalışma izni alma konusunda yaşanan bürokratik sürecin zorluğu olduğu gibi; işverenlerin gelir artırmak amacı ile sigorta, asgari ücret, iş güvenliği ekipman azlı̆̆ı, azami çalışma süresi, mesai ödenekleri, tatil izinleri, kıdem tazminatı gibi haklardan Suriyeli mültecileri yoksun bırakmaları da gelmektedir. (Kocaoğulları, 2020, s.8).

COVID 19 ve alınacak önlemler kapsamında Göçmen Sağlığı Merkezlerine başvuranlar pandemi süreci ile ilgili bilgilendirilmekte, ateş ölçümleri yapılarak, gerekli görüldüğü hallerde hastaneye yönlendirilmektedirler. Göçmen Sağlığı Merkezlerinde çalışan doktor ve sağlık çalışanları için Sağlık Bakanlığı, COVID-19 bilgilendirmelerini Arapça'ya çevirmiştir. Personele eldiven, maske, alkol bazlı el ve yüzey dezenfektanı gönderilmiştir. Ayrıca insanların nasıl el yıkaması gerektiğini anlatan Arapça dokümanlara hem internet aracılığı ile hem de Göçmen Sağlı̆̆1 Merkezlerine giderek öğrenebilmektedirler (Mardin vd., 2020, s.114). Fakat tek başına bilgi sahibi olmak yeterli olmamakla birlikte koşulların farklılıkları da olumsuzlukları artırmaktadır. Örneğin COVID-19 salgını sonucu bulaş riski sebebiyle çalışanların bazıları evden-uzaktan çalışma yöntemi ile faaliyetlerini yürütürken, bazıları ise çalıştığı işin yapısı gereği ya da pandemi öncesindeki eşitsizliklerin devam ediyor olması sebebiyle bundan mahrum kalmaktadır. Hâla dünyadaki istihdam oranının \%61'ini oluşturan 2 milyar kayıt-dışı veya enformel çalışan sayısı böyle bir süreçte mağdur olabilecektir. Özellikle bu tür çalışanlarda iş sağlığı ve güvenliği konusunda karşılaşılabilecek birçok risk faktörü yüksek olup, maske ve hijyen maddesi kullanımı konusunda da yeterince faydalanamama durumu söz konusu olmaktadır. Üstelik bu kesimde yaşayan kişilerin konutları, sağlıklı su şebekesi olmaması, kanalizasyon sorunları gibi sebeplerle genelde sağlıklı yaşam şartları sağlanamamaktadır. Aynı zamanda bu çalışanlar hastalık izni veya işsizlik yardımı gibi sosyal güvenlik haklarından mahrum oldukları için sağlık ile geçim arasında seçim yapma zorunda 
kalabilmektedir (Balcı ve Çetin, 2020, s.21). Bütün bu olumsuz şartlar düşünüldüğünde hem ekonomik anlamda hem de toplum sağlığı anlamında kişi veya kişilere yönelik yaşanmakta olan olumsuz sürecin mülteci ve sığınmacllar açısından da mümkün olduğu görülmektedir. Zira bu kesim toplumda hem risk faktörünün yoğun olarak görüldüğü kesim olarak karşımıza çıkmakta, hem de kendileri ve aileleri olumsuz şartlardan etkilenebilmektedirler.

\section{Sonuç}

COVID-19 salgını ile başlayan ulusal sınırları kapatma, dünya genelinde seyahat kısıtlamaları gibi çeşitli sebepler insan hareketlilikleri noktasında, birçok faktörü toplumsal anlamda değişime uğratmıştır. Bu çalışmada uluslararası göç yönetişimi konusunda; merkezi yönetimden İçişleri Bakanlığı bünyesinde merkez ve taşra örgütünün (Göç İdaresi Genel Müdürlüğü, İl/liçe Göç İdaresi Müdürlükleri), yurt dışı teşkilat yapısının, yerel yönetim birimleri ve sivil toplum kuruluşlarının birlikte hareket etmesinin önemi görülmektedir. Çalışma COVID-19 süreci kapsamında yapılan çalışmaların iş birliği içerisinde gerçekleştirilmesiyle daha etkin sonuçlar alınacağı üzerinde gerçekleştirilmiştir. COVID-19 küresel salgın sürecinin önlenmesi amaciyla sektörler arası diyalog çok daha önemli bir hal almıştır. Özellikle göçmenlerin haklarını koruyan ve göçmenleri destekleyerek çeşitli stratejiler ortaya koyan ve uygulayan, küresel bir sorun olarak adlandırılan bu süreçte ekonomik anlamda koordinasyon sağlayan küresel bir mekanizma kurmak oldukça önemlidir.

Ekonomik anlamda gelişmeler ile yürütülen dışa açılmaya yönelik politikalar Türkiye'nin göç alan ve veren ülke imajını güçlendirmekte, göç için veri sistemlerinin güvenilir olmasını gerekli kılmaktadır. Ayrıca göç ve uluslararası koruma kapsamında kurumdaki hukuksal düzenlemelerdeki eksikliklerinin tamamlanması, bu kapsamdan faydalananların sağlıkta, barınma ve eğitimde kaşısına çıkan problemlerin giderilmesi gerekmektedir. Tüm bu hedeflerin gerçekleştirilmesinde (0nuncu Kalkınma Planı, 2014, s.55; Onbirinci Kalkınma Planı, 2019, s.169):

- Göçe yönelik uluslararası yardım yönetimi, planlaması, uygulama gibi konularda kurumlar arası işbirliğinin güçlendirilmesi, 
- Uluslararası fonlardan ulusal kurum ve kuruluşların doğrudan faydalanabilmesi yönünde kapasitesinin geliştirilmesi,

- Göçün düzenli gerçekleşebilmesi için uluslararası işbirliği,

- Politika ve hizmet sunumlarının sağlanmasında kurumlar arası koordinasyonun geliştirilmesi gibi çalışmalar planlanmaktadır.

Türkiye'de "Yabancilar ve Uluslararası Koruma Kanunu", uluslararası göç bakımından 2013'ten sonra temel oluşturacak nitelikte bir kanun olarak görülmekte olsa bile, devam etmekte olan göçlere yönelik yeni kanunların oluşturulmasi gerekmektedir.

Türkiye'de özellikle belediye gibi sınırdaki yerel yönetim birimleri, Suriye, Irak kaynaklı kitlesel göç hareketleri karşısında çeşitli görev ve rolleri söz konusudur. Karşılaşılan COVID-19 kaynaklı sorunların önüne geçebilmesi yerel, bölgesel ve ulusal anlamda önemli olduğu gibi uluslararası anlamda da kalkınmayı etkileyebilecek bir öneme sahiptir. Bu açıdan sorunların kalıcı hale gelmemesi ve göçmenlerin Türkiye'de sürekli şekilde kalmaları durumunda uyum sorunlarının yanında ortaya çıkan küresel salgının da yerel yönetim birimleri tarafından kamu sektörü, sivil toplum örgütleri ve uluslararası kuruluşlar ile işbirliği halinde çözüme kavuşturulması gerekmektedir. Bu durum onların tek başına hareket etmesinin önüne geçecek kadar karmaşık, birlikte hareket ile hızlı şekilde çözülebilecek nitelikte bir konu olarak görülmektedir. Konunun özellikle göç yönetiminde gerçekleştirilen faaliyetlerdeki aktörler açısından göç gönderen ülkeye, göç alan ülkeye ve transit ülkeye yönelik sorumlulukların eşitlik çerçevesinde paylaştırılması, dengenin oluşturulması gerekmektedir.

İstihdam ve göç, göç yönetişimi açısından ele alınması önemli bir konu olmakla birlikte toplumsal anlamda hem hükümeti hem de alınacak politikalar bazında tüm halkı ilgilendiren bir kondur. Zira göç ederek gelen kişilerin nüfusu sayısal olarak artırmasının yanında, orada gerçekleşecek kültürel farklılıklar daha az istihdam edilmelerine sebep olmaktadır. Ayrıca göç edenlerin farklı dil özellikleri, eğitim konusundaki yetersizlikleri, mesleki becerilerindeki bazı eksiklikler, işverenlerin düşük ücretlerde çalıştırma istekleri, yerel halkın bakış açısındaki olumsuz tavır vb. her türlü etkene, COVID-19 sürecinde yaşanan olumsuzluklar da eklenince pek çok aile açısından geçim sıkıntısı baş göstermiştir. Özellikle sorunların çözüme kavuşturulması ve toplumsal anlamda refah seviyesi oranının yükseltilebilmesi için vatandaşlık haklarının verilmesi ve her türlü haktan yararlanma imkanlarının önü 
açılmalıdır. Zira amaçlarına ulaşabilmek ve her türlü yoksun bırakıldığı imkanlara kavuşmak amacıyla suç oranlarını artııcı faaliyetlere girişimlerde bulunabileceklerdir.

COVID-19 sürecinde testlere ve tedavi yöntemlerine en son erişen kişiler grubunda göçmen işçiler gelmektedir. Göçmen işçiler genellikle ücret, işsizlik veya sosyal güvenlik yardımlarında, sosyal anlamda koruma önlemleri gibi COVID-19'a yönelik ulusal politikalar ve önlemler kapsamın dişında tutulmaktadır. COVID-19 testine veya tedavisine erişimin mevcut olduğu durumlarda bile, özellikle düzensiz göçmen statüsünde olan göçmen işçiler, tutuklanma veya sınır dışı edilme korkusuyla bu hizmete erişemeyebilmektedir (ilo.org). Zira mülteciler arasında işini kaybetme korkusu sebebiyle COVID19 testini yaptırmak istemeyen birçok kişiyi de görmek mümkündür. Bu korkunun önüne geçilebilmesi amacıyla çalışanlara yönelik yapılandırmalara gidilerek güven duygusunun oluşturulması gerekmektedir. 


\title{
EXTENDED ABSTRACT
}

\section{Covid-19 Epidemic and Turkey: Migration Governance Effects}

\author{
Zişan Korkmaz Özcan \\ Süleyman Demirel University
}

From the past to the present, many countries have struggled with the epidemic, sometimes these struggles have been successfully finished in a short time, and sometimes they have passed to a global dimension affecting the whole world in the long term. Policies implemented by countries within the scope of combating epidemic diseases have affected almost every field and segment. In particular, public sector, private sector service providers and regional, national or international organizations that mediate these services are affected by the negatives of the process. Many groups working with the COVID-19 pandemic process all over the world, retired, unemployed, students, young or old, have been affected by this process, as well as people and their families in the so-called migrant and refugee sectors.

The actors of the EU's public sector, private sector and non-governmental organizations, universities and research institutions, associations and their interactions with each other are the elements that provide the information and communication network in migration governance. It is very important for the EU that co-operation on information and communication in migration governance can work correctly.

The study was discussed on three main planes. Firstly, a qualitative research was carried out on migration within the framework of Turkey's Directorate General of Migration Management, secondly, public policies from the past to the present within the framework of migration governance, and thirdly, rhetoric analysis. In this respect, the central and provincial organizations of the central government and local administrations included in the scope of the study, in terms of the public sector; Non-governmental organizations and international organizations, on the other hand, were included in the issue by forming other important segments in the realization of the cooperation movement. In this context, the strategic issues identified were carried out on authorized persons who gave speeches in the context of migration 
during the COVID-19 process. Emphasis has been made on how important migration governance is in the COVID-19 process, the various negatives affecting migrants due to the pandemic, and what needs to be done to support employment and participation.

Migration governance, which emerges as an important concept for the migration management process, has two defining features. First, the word "govern" in the meaning is a decree that is not clearly labelled internationally. Regulated by areas of global governance, migration regulates states' responses to international migration.

In this study, discourse analysis technique, one of the qualitative research methods, was used. Central government, provincial organization of central government, local governments, non-governmental organizations and international organizations that play a role in the institutional structure of migration governance are the areas covered in data collection. The data were collected from people who had speeches in the field of migration during the pandemic process. In this context, the speech of Savaş Ünlü, director general of migration administration of the Ministry of Interior from the public sector, the speech of The Union of Municipalities of Turkey (TBB) and Gaziantep Metropolitan Mayor Fatma Sahin, the speech of Ahmet Türköz, head of the Department of Foreign Relations of the General Directorate of Civil Society Relations as a non-governmental organization, and the speech of Mazen Abhooulsn, IOM Turkey Emergency Program Coordinator of the International Organization for Migration in terms of international organization, were discussed.

As a result of the discourse analysis, it was revealed that the following headings were emphasized in the speeches.

- Emphasis on the Importance of Migration Governance (Cooperation) in the COVID-19 Process

- Emphasis on the Negative Impact of Migrants from the COVID-19 Outbreak

- Emphasis on Participation in Employment and Supporting the Workforce

In this study, on international migration governance; The importance of the central and provincial organizations (Directorate General of Migration Management, Provincial / District Directorates of Migration Management), the foreign organization structure, local government units and non- 
governmental organizations within the Ministry of Internal Affairs are important. The study was carried out on the fact that more effective results will be obtained by carrying out the studies carried out within the scope of the COVID-19 process in cooperation. In order to prevent the COVID-19 global pandemic, inter-sectoral dialogue has become much more important. In particular, it is very important to establish a global mechanism that protects the rights of immigrants and puts forward and applies various strategies by supporting migrants and provides economic coordination in this process, which is called a global problem.

In Turkey, the ability of local government departments / municipalities, especially on the border, to prevent COVID-19-related problems in the face of acute mass migration movements from Syria and Iraq is important locally, regionally and nationally and can affect development internationally. In this respect, the problems should not become permanent and the global epidemic that arises in addition to the adaptation problems if the migrants are permanent residents in Turkey should be solved by local government departments in cooperation with the public sector, NGOs and international organizations.

Employment and migration are an important issue to address in terms of migration governance, but they are a social issue that concerns both the government and the whole public on the basis of the policies to be taken. This is because, besides the numerical increase in the population of immigrants, cultural differences that will take place there cause them to be employed less. In addition, the different language characteristics of the migrants, their inadequacies in education, some deficiencies in their professional skills, employers' desire to employ workers at low wages, negative attitudes from the point of view of the local people, etc. added to all kinds of factors, including the negativity experiences in the COVID-19 process are the factors that have arisen the shortage of livelihoods for many families.

Migrant workers are the last people to have access to testing or treatment during covid-19. Migrant workers are often excluded from national COVID19 policy measures such as wage benefits, unemployment benefits or social security and social protection measures. It is also possible to see many people among refugees who do not want to be tested on COVID-19 for fear of losing their jobs. In order to prevent this fear, it is necessary to establish a sense of trust by going to the configurations for employees.

Kaynakça / References 
Aliu, A., Oğurlu, Y., Özkan, Ö., Öztürk, İ. ve Aliu, D. (2017). Avrupa Birliği hukuku kapsaminda göç yönetişimi, yetkilendirme, yetki ikamesi ve ölçülülük ilkesi. Siyaset, Ekonomi ve Yönetim Araştırmaları Dergisi (SEYAD), 5(3), 95-107.

Aydın Düzgit, S., (2011). Avrupa Birliği-Türkiye ilişkilerine postyapısalcı yaklaşım: Almanya örneğinde dış politika ve söylem analizi, Uluslararası İlişkiler Dergisi, 8(29), 49-70.

Balc1, Y., ve Çetin, G. (2020). Covid-19 pandemisinin Türkiye Ekonomisinde istihdam ve çalısma hayatı üzerindeki etkileri: Sorunlar ve çözüm önerileri. İstanbul Ticaret Üniversitesi Yayınları.

Başaran, İ. (2007). Sağlık kentler kavramının gelişiminde sağlıklı kentler projesi. Dokuz Eylül Üniversitesi Sosyal Bilimler Enstitüsü Dergisi, 9 (3), 207-229.

Belli, A. (2019). Türkiye' de sağlıklı kentler ve büyükşehir belediyeleri üzerine karşlaştırmalı bir analiz. OPUS Uluslararası Toplum Araştırmaları Dergisi, 10(17), 1930-1962.

Betts, A. (2008). Global migration governance. Global Economic Governance (GEG) Working Paper, WP, 43.

COVID-19 pandemisinde göçmen işçileri korumak (Nisan 2020). İlo. 03.01.2021 tarihinde https://www.ilo.org/wcmsp5/groups/public/---europe/---rogeneva/---ilo-ankara/documents/publication/wcms 745357.pdf adresinden erişildi.

Demirhan, Y., ve Aslan, S. (2015). Türkiye'nin sınır ötesi göç politikaları ve yönetimi. Birey ve Toplum Sosyal Bilimler Dergisi, 5(1), 23-62.

Duhl, L. J. (1986). The healthy city: Its function and its future. Health promotion international, 1(1), 55-60.

Europarl. (t.y). A global compact on migration, Placing human rights at the heart of migration management. 02.02.2021 tarihinde https://www.europarl.europa.eu/RegData/etu-

des/BRIE/2017/614638/EPRS_BRI(2017)614638_EN.pdf adresinden erişildi.

Goldstein, G. (1996). A healthy city is a better city. World Health, 49(1), 4-6. 10.01.2021 tarihinde http://www.goc.gov.tr/icerik/hakkimizda 308 309 adresinden erişildi.

Göç İdaresi Genel Müdürlüğü Yayın Yönetmeliği, (23.05.2020). Resmi Gazete, 20.12.2020 tarihinde https:/www.mevzuat.gov.tr/mevzuat?MevzuatNo=34544\&MevzuatTur=7\&MevzuatTertip $=5$ adresinden erişildi. 
Göç Kurumu. (2016). 2016 Türkiye Göç Raporu. 20.01.2021 tarihinde https://www.goc.gov.tr/kurumlar/goc.gov.tr/files/2016_yiik_goc_raporu haziran.pdf adresinden erişildi.

Kara, D., Öykü, C. ve Kara, M. (2015). Türkiye'de göç yönetişimi: kurumsal yapı ve işbirliği. Journal Of Entrepreneurshıp And Development, 10(2), 1-25.

Kocaoğulları, A. (Aralık 2020). Kentsel hizmetlere göç perspektifinden bakmak: Pandemi döneminde İstanbul Örneği Ulusal Düzeyde Karar Alıclar için Politika Önerileri. Heinrich Böll Stiftung Derneği Türkiye Temsilciliği.

Kolukırık, S. (2014). Uluslararası göç ve Türkiye: Yerel uygulamalar ve görünümler. Zeitschrift für die Welt der Türken/Journal of World of Turks, 6(2), 37-53.

Korkmaz Özcan, Z. (2018). Kamu politikaları çerçevesinde Türkiye' de göç yönetişimi: Merkez- taşra yapılanması. 6. Uluslararası Çin'den Adriyatik'e Sosyal Bilimler Kongresi Özet Kitabı, Ankara.

Korkmaz Özcan, Z. ve Gül, H. (2019). Kentsel güvenlik açısından geçici koruma kapsamındaki Suriyelilerin iller bazında değerlendirilmesi. Kamu Yönetimi Seminerleri -KAYSEM 13 (1316-1326). Gaziantep, Turkey.

Korkmaz Özcan, Z. ve Mesci, H. (2018). 4771 sayılı çeşitli kanunlarda değişiklik yapılmasına ilişkin kanun çerçevesinde göç ve yönetişim ilişkisi, Küresel ve Yerel Bakış Açısıyla Sosyal Bilimler Araştırmaları, SRA Academic Publishing.

Mardin, D., Özvarış, Ş. B., Sakarya, S., Kayı, İ., Gürsoy, G., Yukarıkır, N., ve Başpınar, A. (2020). Covıd-19 sürecinde Türkiye'de göçmen ve mültecilerin durumu. Sağlık ve Toplum Özel Sayı. 01.11.2020 taihinde https://ssyv.org.tr/wp-content/uploads/2020/07/14-Cov\%C4\%B1d-19S\%C3\%BCrecinde-T\%C3\%BCrkiye\%E2\%80\%99de-

G\%C3\%B6\%C3\%A7men-ve-M\%C3\%BCltecilerin-Durumu.pdf adresinden erişildi.

Mülteciler.org. (t.y). Türkiye'deki Suriyeli sayısı. 01.02.2021 tarihinde https://multeciler.org.tr/turkiyedeki-suriyeli-sayisi// adresinden erişildi. https://turkey.iom.int/tr/g\%C3\%B6\%C3\%A7-ve-entegrasyon adresinden erişildi.

Newland, K. (2020). Will international migration governance survive the COVID19 pandemic? Policy Brief, Migration Policy Institute.

Papademetriou, D. G. (2011). Governance of international migration: Defining the potential for reform in the next decades. Migration Policy Institute, Lizbon.

Portes, A. (2008). Migration and Development: A conceptual review of the evidence. S. Castles, ve R. D. Wise, Migration And Development: Perspectives 
From The South. içinde (s.17-43) .Geneva: International Organization for Migration,

SBB. (t.y). On Birinci Kalkınma Planı (2019-2023). 10.01.2021 tarihinde https://www.sbb.gov.tr/wpcontent/uploads/2019/07/OnbirinciKalkinmaPlani.pdf adresinden erişildi.

SBB. (t.y). Onuncu Kalkınma Planı (2014-2018). 10.01.2021 tarihinde https://www.sbb.gov.tr/wp-content/uploads/2018/11/OnuncuKalk\%C4\%B1nma-Plan\%C4\%B1-2014-2018.pdf adresinden erişildi.

Sözen, E. (1999). Söylem: Belirsizlik, mübadele, bilgi, güç ve refleksitive. İstanbul: Paradigma Yayınları.

T.C Sağlık Bakanlığı (t.y). COVID-19 Bilgilendirme Sayfası. 19.01.2021 tarihinde https://covid19.saglik.gov.tr/TR-66300/covid-19-nedir adresinden erişildi.

Tepealtı, F. (2019). Avrupa Birliği'ne yönelik Türkiye geçişli (transit) göç hareketleri ve Türkiye'nin düzensiz göçle mücadelesi. Doğu Coğrafya Dergisi, 24(41), 125-140.

Türkiye Belediyeler Birliği. (t.y). Şahin Türkiyenin pandemide ki başarısını anlattı. 09.012.2020 tarihinde https://www.tbb.gov.tr/basin-ve-yayin/haberler/20200612-sahin-turkiyenin-pandemideki-basarisini-anlatti adresinden erişildi.

Un. (t.y). International Migration 2020 Highlights. 05.02.2021 tarihinde https://www.un.org/en/desa/international-migration-2020-highlights adresinden erişildi.

\section{Kaynakça Bilgisi / Citation Information}

Özcan Korkmaz, Z. (2021). Covid-19 salgını ve Türkiye: Göç yönetişimi üzerindeki etkileri. OPUS-Uluslararası Toplum Araştırmaları Dergisi, 17(Pandemi Özel Say1s1), 3808-3831. DOI: 10.26466/opus.883997 